\title{
A SYSTEMS THINKING APPROACH TO THE SUSTAINABILITY OF QUALITY IMPROVEMENT PROGRAMMES
}

\author{
D.J . van Dyk $^{1 *} \&$ L. Pretorius ${ }^{2 \dagger}$ \\ ${ }^{1,2}$ Graduate School of Technology Management \\ University of Pretoria, South Africa \\ 2leon.pretorius@up.ac.za
}

\begin{abstract}
The challenge for organisations to continually provide the best return on investment for their shareholders has become increasingly difficult through globalisation of the market place. There are many responses a company could make to these challenges - for example, new product development, increased market capitalisation, cost reduction initiatives, and quality management. This last response focuses on, but is not restricted to, customer satisfaction, continuous improvement, and environmental impact. Continuous improvement addresses waste in the business design and manufacturing processes, which could lead to improved profit margins. The sustainability of quality improvement programmes remains a challenge. Causality can be studied, using Six Sigma tools, to relate cause and effect. But these tools do not always allow the user to study and understand feedback from other factors, such as soft human issues, in the improvement process system, typically referred to as 'feedback causality'. System dynamics may improve this understanding. Quality improvement programmes in the heavy engineering manufacturing environment are not researched to the same degree as those in the automotive manufacturing environment. The purpose of this paper is to share results from research into the sustainability of quality improvement programmes, and the development of an appropriate system dynamics model, using qualitative case study data gathered and coded in a heavy engineering manufacturing environment.
\end{abstract}

\section{OPSOMMING}

Die uitdaging vir organisasies om deurentyd vir aandeelhouers die beste opbrengs op hul belegging te verseker word al hoe moeiliker as gevolg van internasionalisering van die mark. Daar is vele aksies wat ' $n$ firma kan neem om die uitdagings aan te spreek - byvoorbeeld nuwe produk ontwikkeling, vermeerdering van mark kapitalisasie, koste besnoeiingsinisiatiewe, en kwaliteitsbestuur. Laasgenoemde fokus op, maar is nie beperk tot, klant tevredenheid, kontinue verbetering, en omgewingsimpak nie. Kontinue verbetering spreek onder andere vermorsing of oortolligheid in besigheidsontwerp en vervaardigingsprosesse aan, wat kan lei to verbeterde winsmarge. Volhoubaarheid van kwaliteit verbetering programme bly egter ' $n$ uitdaging. Oorsaaklikheid kan bestudeer word deur gebruik te maak van 'Six Sigma' hulpmiddels. Maar hierdie hulpmiddels laat nie altyd die gebruiker toe om terugvoer vanaf ander faktore soos sagte menslike kwessies in die proses verbetering stelsel te bestudeer en verstaan nie. Die gebruik van sisteem dinamika kan hierdie situasie verbeter. Kwaliteit verbetering programme in die swaar vervaardiging omgewing word nie altyd in dieselfde mate nagevors as in die motorvoertuig vervaardiging omgewing nie. Die doel van hierdie artikel is sekere navorsingsresultate t.o.v. die volhoubaarheid van kwaliteit verbetering programme te deel. 'n Tersaaklike sisteem dinamika model is ontwikkel deur gebruik te maak van kwalitatiewe gevallestudie data wat versamel en gekodeer is in 'n swaar vervaardiging omgewing.

\footnotetext{
* The author was enrolled for a PhD in the Graduate School of Technology Management at the University of Pretoria, South Africa

${ }^{\dagger}$ Corresponding author
} 


\section{INTRODUCTION}

Organisations are challenged to provide the best return on investment for their shareholders. In order for companies to stay competitive in the global market, they need to adapt to changing market needs. Focus on quality leads directly to an increase in productivity and to other benefits, due to the ability of the company to produce standardised products, reduce variation, and increase the efficiency of its processes [1]. In manufacturing operation, quality improvement programmes such as Six Sigma are used to improve quality and reduce cost. Continuous improvement is defined as a "culture of sustained improvement targeting the elimination of waste in all systems and processes of the organisation" [2]. One of the steps in the design and analysis phase of the improvement process is the use of simulation and design of experiments (DoE) to find the transfer function between the voice of the customer (VOC) and the voice of the process (VOP). During these simulations, the influence of the different factors is simulated; but the influence of intangible issues such as stakeholder involvement, policies, training, management support, and other related issues is not always simulated in appropriate detail.

Generally, the understanding of the dynamic behaviour of the improvement process is poor and the relationships with these intangible issues are not clear; and so they are not always taken into account during modelling. System dynamics is an approach that may improve this understanding. From a system dynamics point of view, the effect of these issues on the interaction with the tangible issues can be modelled and therefore studied in more detail. The structures for which quantitative metrics are available are sometimes referred to as 'hard' variables, where the term 'hard' is intended to show that numerical data is more suitable for mathematical enquiry than qualitative data [3]. This provides a better view of the dynamic behaviour of the complete system in relation to the improvements made by a quality improvement process such as Six Sigma. In a study done by Baines and Harrison [4], it is noted that manufacturing system modelling has been a missed opportunity for system dynamics modelling, especially in the higher levels of decision-making. It is in these cases that system dynamics can serve a useful role in Six Sigma practice [5].

A research study was launched to explore why initially successful improvement programmes fail, with the aim of designing a sustainable improvement programme [6]. Preliminary results from this study show that even highly successful quality programmes can, under certain conditions, lead to a short-run deterioration in financial results and to the subsequent loss of commitment to the quality programme. Jones et al. [6], in their research into one particular company, found that management is faced by challenges when they launch multiple quality improvement programmes. In further research [7], it has been established that the following three basic resources appear to be needed to sustain an improvement programme: (1) employee time; (2) managerial time; and (3) skill with programme tools. Successful Total Quality Management (TQM) programmes are underpinned by continuous improvement over time; and so sustainability becomes an indispensable factor [8].

Buchanan et al. describe sustainability as follows: "Sustainability implies that new working methods and performance levels persist for a period appropriate to the setting" [9]. Buchanan et al. [9] further identify 'managerial' (style and behaviours) and 'leadership' (vision and goals) as some of the factors that ensure sustainable quality improvement programmes. The interaction of the components in sub-systems determines the outcome of the system as a whole, and is dynamic and complex [27]. Stamatis [27] further postulates that the system may be described by system dynamics, which is an approach for modelling and studying the behaviour of a system over time. It is a methodology and computer simulation technique used to model complex processes and problems. System dynamics originally started in corporate management applications, and was later expanded into understanding the behaviour of urban development - and even later to understanding the behaviour of the global economic crisis [28]. 
Repenning and Sterman developed a theoretical dynamic model, based on system dynamics (SD), in order to study the interaction between the allocation of resources time and process improvements to meet production demands [10]. Figure 1 shows the system dynamics model for quality improvement programmes proposed by Repenning and Sterman [10], in a study conducted in the automotive industry. In a recent study conducted by Van Dyk and Pretorius [11], the systems dynamics model developed by Repenning and Sterman [10] (Figure 1) is adapted and proven to be applicable in a heavy engineering manufacturing environment. The details of the elements and fundamentals of this model are explained in the expansion and further development of this model in the ensuing sections of this paper.

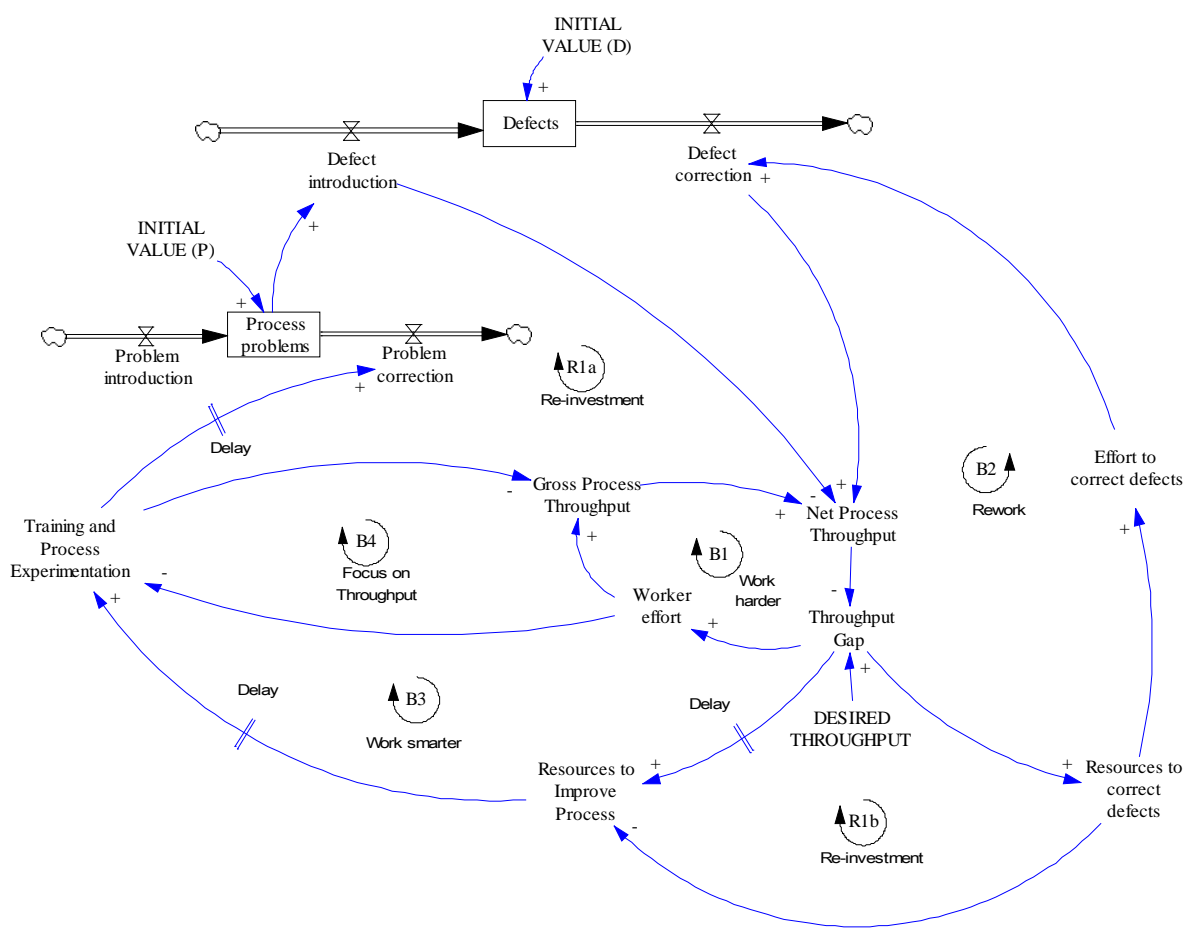

Figure 1: System dynamics model of a quality improvement programme adapted from Repenning and Sterman [10]

The development of the theory for sustainable quality improvement programmes, as described in this paper, has been grounded in the literature and case studies through a qualitative research design. As stated earlier, Buchanan et al. [9] describe sustainability as follows: "sustainability implies that new working methods and performance levels persist for a period appropriate to the setting". The authors further postulate that sustainability is about the stability of work methods. The term 'work methods', in the study reported in that paper, refers to the methods associated with the operational excellence and Six Sigma quality improvement programmes, demonstrated in the case studies. They further postulate that sustainability could also be the consistent achievement of performance goals, and might also apply to the maintenance of the consistent trajectory of performance improvement, which inherently implies consistent measurement of the improved process.

In their research, Buchanan et al. [9] identified eleven factors affecting sustainability. The factors they highlighted were 'managerial' (style and behaviours), 'leadership' (vision and goals), and 'process' (implementation methods). The management and leadership aspects are indicative of management support for the quality improvement programme, while the implementation methods refer to the tools used to implement the quality improvement programme and their long-term use. Bateman and Rich [24] found that a lack of resources inhibits sustainable process improvement programmes. This was also the focus of the study 
of Repenning and Sterman's [10] systems dynamic model of a quality improvement programme in an automotive environment.

Zairi [25] proposed a model that led to continuous improvement of processes, products and services, and employee fulfilment. In one element of the model, sustainable performance, measurement is an important aspect. Another element of the model, process management practices, brings about incremental improvements, which inherently means a culture of continuous improvement. Committed and involved management that provides organisational support, and performance measures for improved process - these were two of the important factors identified for sustainable quality improvement programmes [12].

Measurement of improved processes, and effective usage of the quality improvement programme tools (consistently over time) with management support, were identified in this research as key possible elements for the sustainability of the quality improvement programme. During this research, these two key elements were further expanded in theorybuilding that was grounded in the literature.

\section{RESEARCH DESIGN AND METHODOLOGY}

This paper is focused on the operational management of operations, specifically in a heavy engineering manufacturing industry. The organising framework for the underlying research is descriptive, and an applied research- or problem-based approach is followed to address an existing problem [13]. Another organising framework for this study is qualitative research, where the purpose is to 'get under the skin' of the organisation to find out what really happens, and to carry out research into the processes leading to results [14].

The research design is a polar type research design, where the case studies focus on initiatives that were either dramatic successes or dramatic failures, with the expectation that their comparison would help identify those processes that prevent competenceenhancing change [15]. The literature points out that case or field research is often preferred over the more traditional rationalist methods of optimisation, simulation, and statistical modelling for building new operations management theories [16].

The data has been gathered through semi-structured interviewing (individual), documentary resources, and computer simulation studies [17] and other existing data as the primary source. Intrinsic case studies of the currently employed quality improvement process of the real life problem are investigated, where the boundaries are set by the criteria determined by the research problem.

The research questions address the fundamental question 'How', where the case study is the most appropriate method to be used. These research questions are aligned with the research objective in order to answer the fundamental questions and so to develop a theory of sustainability of quality improvement programmes. The aim with this paper is to answer the following research questions: (1) How does the implementation of the quality improvement programme influence the dynamic behaviour of the manufacturing process? and (2) How do less tangible factors impact the dynamic behaviour of the quality improvement programme? Adapted from Rule and John [18] is a list of level II field questions, data sources, and instruments used during this research. The unit of analysis for this research is defined by studying the dynamic behaviour of the manufacturing process in a heavy engineering manufacturing environment where quality improvement programmes have been implemented. Through grounded theory, themes or concepts are identified across the written database, such as transcriptions of interviews, where the main aim is to link these concepts to generate meaningful theories through identifying relationships among factors in the system [19].

In the case studies proposed in this paper, two cases have been identified where the implementation of one quality improvement programme has been less successful than the 
implementation of another. However, in both instances the same executive has led the implementation of the two different quality improvement programmes.

The first case study, done in the machine shop of a heavy manufacturing concern, is evidence of one of the more successful implementations of a quality improvement programme. The second case study, done in the manufacturing and assembly plant, describes one of the less successful implementations of a quality improvement programme. As recalled in evidence by the operational excellence manager: "The wave in the machine shop has been more successful than in the manufacturing and final assembly". The operational excellence implementation measurement report, contained in the case study database, confirmed this statement.

During the analysis phase, the data has been coded to a slightly higher conceptual level and grouped together. Items that seemed to be essentially similar have been assigned the same code. The higher conceptual level was the enabler to sort the items into similar groups, giving more insight into them. This sorting method has been summarised into a matrix format that is too big to include in this paper but is available with the case study database on request.

\section{QUALITY MANAGEMENT AND THE INFORMATION FEEDBACK LOOP}

Management decision-making is a process of converting information into action; and so management success depends primarily on what information is chosen and how the conversion is executed [20]. This is a framework, in its simplest form, of an informationfeedback system. Information is the input to the decision-making point that controls action, which in turn yields new information. The decision is based on the state of the system. Figure 2 is a schematic diagram of the decision and information feedback loop adapted from Morecroft and Sterman [20].

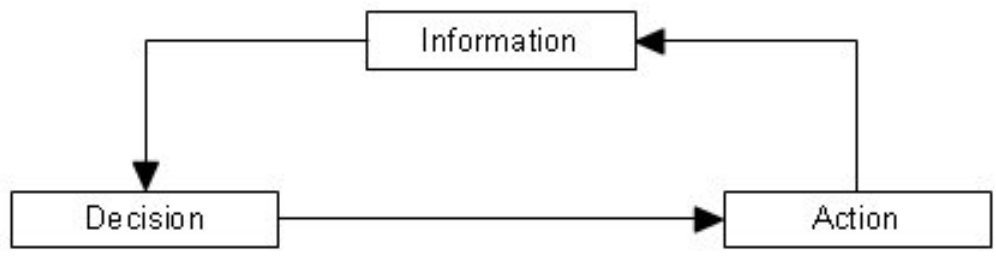

Figure 2: Decision and information feedback loop [20]

Decisions are determined by decision-making rules, which are policies and protocols specifying how the decision-maker processes the available information that governs the rates of flow in systems. Decisions are therefore the result of applying decision rules to the available information cues, where these cues are generated by measuring and reporting processes, in the physical and functional structure of the system [3] (Figure 3).

Measuring processes are one of the key elements of the successful implementation of sustainable quality improvement programmes, by controlling in-process performance using measures such as defect reduction and control charts [21]. Measurements are a fundamental part of the continuous process improvement cycle, which is based on the Deming cycle of plan, do, check and act (Figure 4). Phase 5, 'Study the results', has the objective of monitoring and evaluating the change by tracking and studying the effectiveness of the improvement efforts through data collection and progress review. The ongoing measurement and evaluation efforts might lead to continuous improvement [12].

The measurement process creates a feedback loop in the system: from the data gathered from the output of the actions taken during the quality improvement programme; through the decision-making process; eventually to changing the state of the system. 


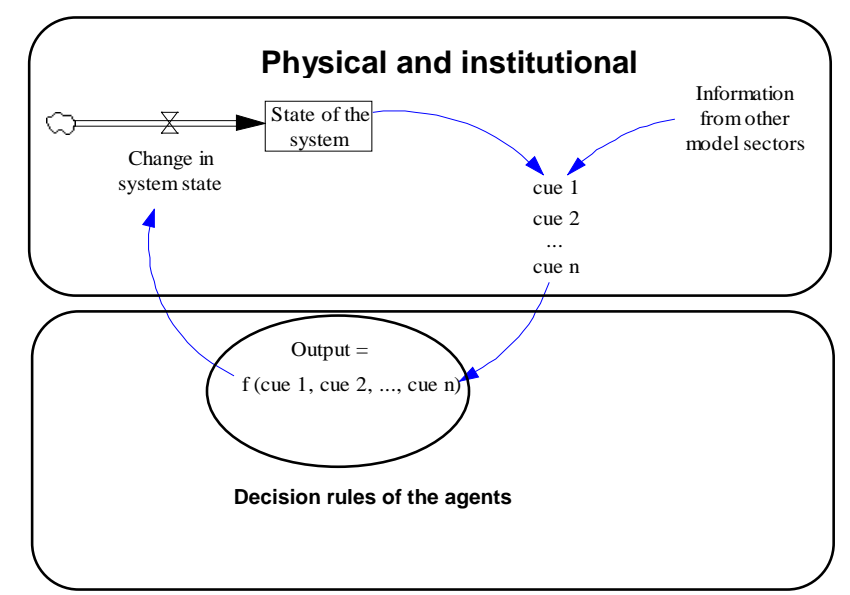

Figure 3: Decision rules adapted from Sterman [3]

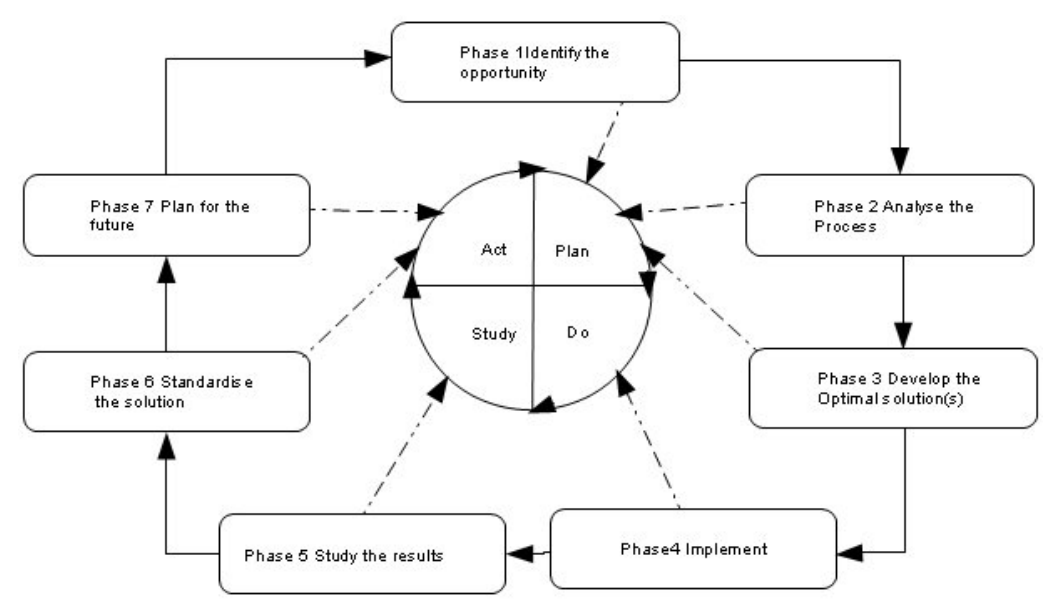

Figure 4: Continuous improvement cycle adapted from Besterfield et al. [1]

These measurements are discussed by the different teams and management during the departmental meetings and cell board meetings, as depicted typically by operational excellence and lean Six Sigma quality improvement programmes [21]. During these discussions the measurements are compared with the original goals and objectives determined at the implementation of the quality improvement programme. When the actual measurements deviate from the goals and objectives for the relevant processes, the team and management discuss corrective actions, aimed at the root causes, to close the gap between the actual measurements and the original goals and objectives.

Different measurements are used during the implementation of typical quality improvement programmes such as Six Sigma, Lean Six Sigma, and Lean [21]. Run charts are one such measurement that enables the team to study the data for trends and patterns. Process sigma is another measurement method that measures process performance from the customer's perspective by demonstrating the variation relative to the customer or target specification. The process sigma value is based on the defects per million opportunities (DPMO), where a high process sigma value depicts a high process performance with less variation, and a low process sigma value depicts a low process performance with more variation [26]. 


\subsection{Reference mode of the dynamics for the implementation of a quality improvement programme determined from this research}

The reference mode associated with the dynamics for the implementation of a quality improvement programme in this research is displayed in Figure 5 . The reference mode describes the dynamic behaviour of the impact of the implementation of a quality improvement programme in the machine shop of a heavy manufacturing concern. The data for the reference mode has been gathered from archived data and semi-structured interviews during the polar type case study design, where the case studies focus on initiatives that were either dramatic successes or dramatic failures. The reference mode is measured in defects per unit, and the time horizon is sufficient to demonstrate the dynamics associated with the quality improvement programme, both before and after the implementation of a quality improvement programme such as Six Sigma. A Six Sigma quality improvement programme was successfully implemented and rolled out in the machine shop from May 2010. The decline in defects per unit is clearly visible from May 2010 through to August 2011.

Defects per unit plot

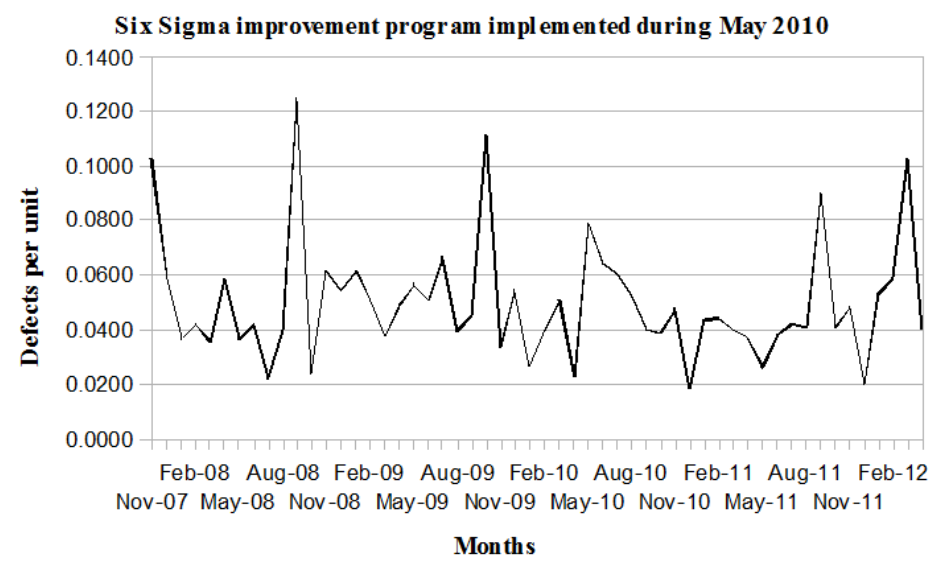

Figure 5: Reference mode of the defects per unit measured for the machine shop

\section{4 \\ SYSTEM DYNAMICS MODELLING AND THE QUALITY MANAGEMENT INFORMATION FEEDBACK LOOP}

\subsection{Dynamic hypothesis}

A dynamic hypothesis is constructed from the reference mode shown in Figure 5. A dynamic hypothesis is a theory that characterises the behaviour of the system under study. The hypothesis is dynamic because it provides an explanation of the dynamics characterising the behaviour in terms of the underlying feedback and stock and flow structure of the system. It is a hypothesis because it is always provisional, subject to revision or abandonment as more is learnt from the modelling process and the real world [3]. The dynamic hypothesis therefore guides the modelling efforts by focusing on certain structures.

The display of the time series plot for the reference mode in Figure 5 is the typical recorded behaviour of the manufacturing system after the implementation of the Six Sigma quality improvement programme in the machine shop. The data clearly demonstrated decay over time, from May 2010 onwards, which is typical for a balancing feedback loop depicted by goal-seeking behaviour where negative feedback loops act to bring the system in line with a goal or desired state [3]. A typical structure of a system dynamics model for a balancing feedback loop is shown in Figure 6, while the simulation results for the behaviour are displayed in Figure 7. The state of the system is depicted by the stock of the system, which is the numerically-integrated result of the input rate (corrective action) that changes the stock at an average adj ustment time [3]. 


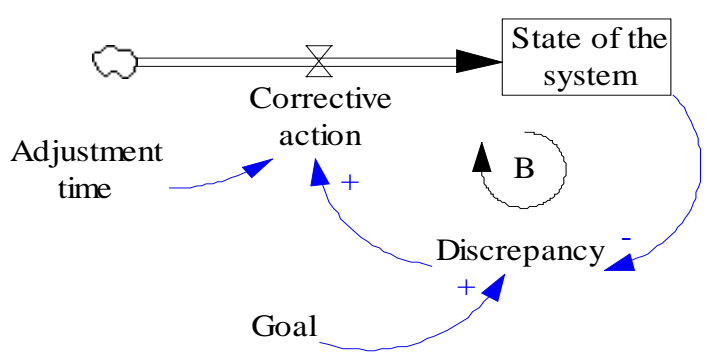

\section{Figure 6: A typical balancing system dynamics feedback loop structure with goal-seeking} behaviour

The state of the system is compared with the goal, which in this instance is 1 . If there is a discrepancy between the desired state or goal and the actual state, corrective action is initiated to bring the state of the system back in line with the goal. The corrective action is the rate at which the system changes at an average equal to the adj ustment time.

The rate at which the system approaches its goal reduces as the discrepancy gets less. This behaviour is depicted as a goal-seeking behaviour that is typical for an exponential decaying behaviour [3] (Figure 7). This decline (as shown in Figure 5) began in May 2010, since the Six Sigma was implemented between April 2010 and October 2010, and is typical for an exponential decay. If exponential regression analysis is done with the data during this period, the relationship in equation (1) arises.

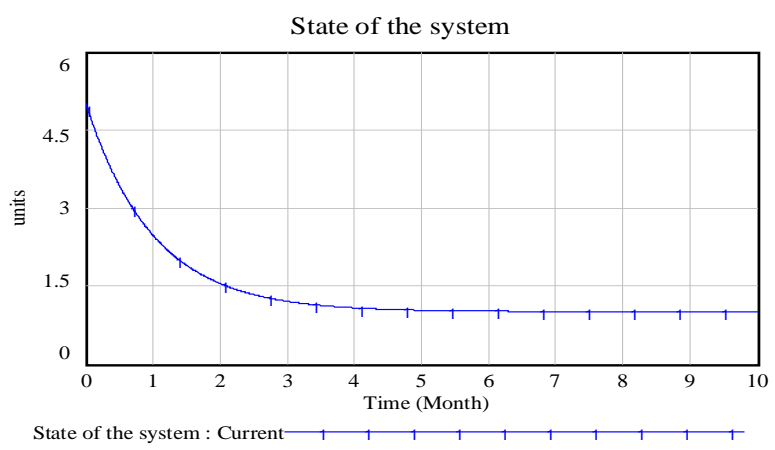

Figure 7: Simulated dynamic behaviour of a typical balancing feedback loop with goalseeking behaviour, based on the structure in Figure 6

Equation (1) describes the relationship between defects per unit and time in months, with a $R^{2}$ value of 0.97 . The $R^{2}$ is an indication of how well the regression equation fits the data. The more accurately the equation fits the data, the closer the $R^{2}$ is to 1 (see Figure 8 ).

$$
\begin{aligned}
& y=0.0892 * e^{-0.14 * t} \\
& \text { where } t=\text { Time in months }
\end{aligned}
$$

Equation (1) describes the equation for an exponential decay of the manufacturing process studied in this research, which equates to a half-life of approximately 7.1 months. This means that every 7.1 months the value for the y variable could halve. In an empirical study done on different processes in order to arrive at a model to assist with the setting of quality goals, the half-life for manufacturing scrap is reported to be seven months, and the half-life for defects per unit is reported to be 7.6 months [22]. If the equation is extrapolated to December 2011, the data roughly follows the regression line until December 2010. From December 2010 onwards the data breaks away from the regression line and shifts upwards. The exponential regression equation is therefore only appropriate 
for the time between May 2010 and October 2010, with a $R^{2}$ of 0.97 . Figure 9 shows the extrapolated data up to December 2011.

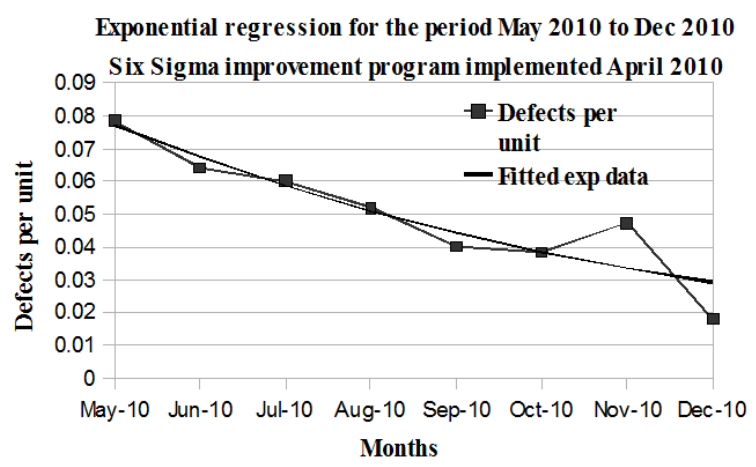

Figure 8: Exponential regression of defects per unit data from May 2010 to December 2010

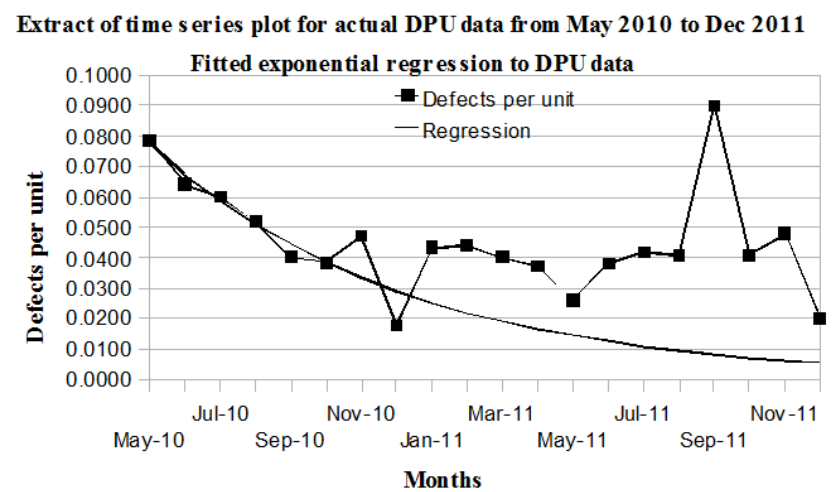

Figure 9: Extrapolated exponential regression data up to December 2011, against the plot of the exponential decay depicted in equation (1)

Since the implementation of the Six Sigma quality improvement programme, the negative feedback loop or balancing loop behaviour of the data could be an acceptable dynamic hypothesis for the structure and behaviour of a measuring process; and this could be integral to the implementation of a quality improvement programme [12], [21].

The output from the measurement process is endogenous to the structure of the quality improvement programme. Management could use the measurement of the defects in the measurement process as a guide to finding the discrepancy between the actual defective units of the system and the goal or target of defective units for the system. The discrepancy could lead management to make corrective actions, bringing the process back to the original goal or target. The discrepancy could be due to defects such as the process not delivering on time, defective materials or parts, or the process sigma value not being on target.

\subsection{A system dynamics model of sustainability from a systems thinking perspective}

The dynamic hypothesis developed in the previous section of the paper and shown in Figure 6 is now further expanded in developing a system dynamics model of sustainability for a quality management information feedback loop. No process is perfect, and therefore defects may be part of the characteristics of any process. Defects in a process can include late delivery (if it is a service process) or defective material (if it is a manufacturing process, such as that reported on in this paper). The primary goal of a quality improvement programme is to reduce the defects in a process by decreasing the rate of defect 
introduction. The rate of defect introduction is a function of process problems, where the process problem may not be visible to the manager of the process.

Process problems within a process could typically be machines that are not calibrated, machine operators who are not fully trained to use measurement equipment correctly, or a machine operator who needs glasses to read a measurement instrument accurately. As evidence of this effect, the operational excellence manager recalled: "...we introduced process boards, visual performance boards...". He continued: "Opex [operational excellence] is wide, we looked at the different aspects of all processes as well... I have measurements... from these reject reports... we have a defect analysis... that will tell us first of all the machines, it will tell us the type of defect." The process problem is typically the root cause of the defect, and thus the origin of the defect. See Figure 10 for a system dynamics model of defects and process problems extracted from Figure 1.

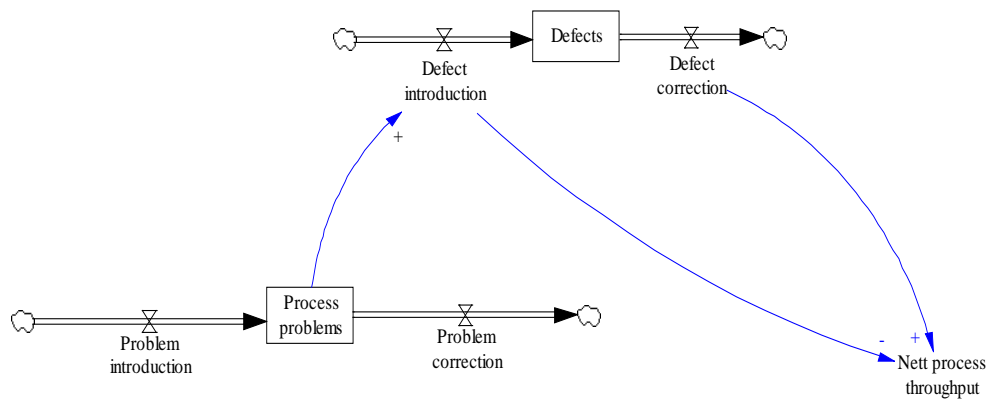

Figure 10: System dynamics model of process problems and defects, extracted from Figure 1

Finding the root cause of a defect may typically be one of the goals of a Six Sigma quality improvement programme, where a typical tool could be the fish bone diagram or the causeand-effect diagram. The business unit manager of the machine shop recalled: "We try and track the defect at the point of the defect...". This manager machine shop then recalled: "Is it the operator, is it the machine, is it measuring equipment... and then we target that problem and fix it...".

To achieve the goal of the quality improvement programme, measurements are typically implemented across the process. Measurements could be used to compare the defects measured in the process with a target or desired defect level. The desired defect level is typically set by the quality department, and may typically be measured and reported on at a fixed frequency. Figure 11 depicts a system dynamics model for the measurement process. The defect gap is the difference between the actual number of defects in the process and the desired defect level.

The quality manager in the machine shop recalled: "We are measuring the defects per unit every month. I [the quality manager] capture the information and do the graphs [DPU graphs] and give it to management with root causes as well as cost... We measure the process to make sure the defects per unit are not more than the target."

The information about the defect gap is not immediately available, but is reported to management on a monthly basis, as recalled by the quality manager. This is described as a typical information delay (shown in Figure 11). Management allocate some of their time to use this information in determining whether the manufacturing process is still capable of delivering the product at the desired quality level; they also use this information to manage their respective processes in achieving the overall business goals.

If the information indicates that the respective processes are possibly not capable of delivering the product at the desired quality level, management time may be allocated to 


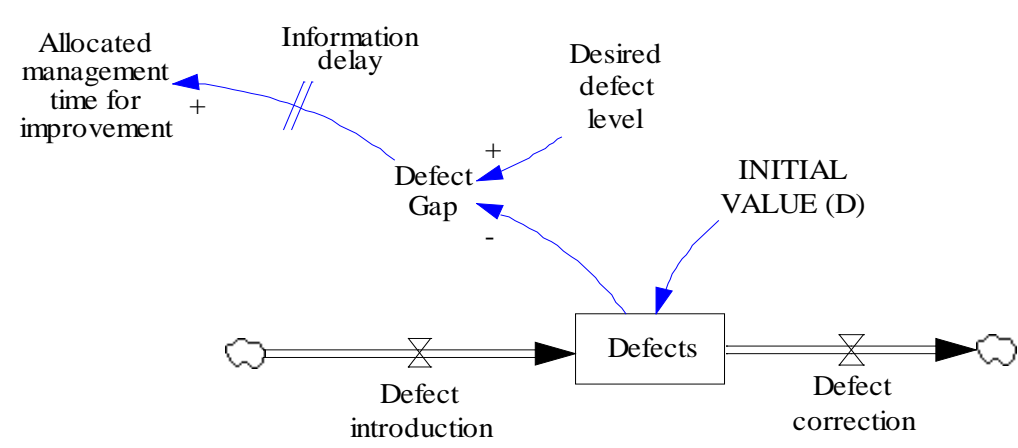

Figure 11: System dynamics model with defects measurement

manage the defect gap. The business unit manager of the machine shop recalled: "I [the machine shop manager] have measurements... from these reject reports... we do a defect analysis... we will zoom in and find exactly what the problem is...". The quality manager also recalled: "We [the quality management team] will measure the process to make sure the defects are not more than the target...".

Management would typically allocate some of their management time to investigate the root cause of the defects that prevent the process from delivering the product at the desired quality level. Part of their management time allocation could be for meetings with the production team, and to support the team that investigates the defects, typically using tools such as cause-and-effect diagrams. The technical supervisor for the machine shop recalled: "We [management] meet with the cell team members to find out what went wrong... then we will have physical interviews with the team leader and operator and ask what went wrong... we identify the problem and eliminate the problem going forward...". The quality manager commented on the question of the management's commitment to the quality improvement programme as follows: "I never had any negative feedback from management...".

The management time allocated for improvement is deducted from the total management time that they have available per week to perform their normal managerial duties, such as attending business related meetings, managing-by-walk-about, planning duties, and following up typically on production output, state of the processes, and human resource activities. The team leader machine shop recalled: "...I spend about $20 \%$ to $30 \%$ of my time on the shop floor... I also have meetings... discussing HR and IR issues... discussing the machines that are not working... making sure I get my recoveries". When the defect gap is bigger than the desired defect level, managers typically allocate more time to the quality improvement programme than they do when the defect gap is equal to or less than the desired defect level. The additional focus on the quality improvement programme could create pressure on management: managers typically experiences time pressure to meet all their managerial requirements. The increase in management pressure usually has a negative impact on managers' effectiveness, because they typically find it difficult to manage their time [23]. Figure 12 gives the system dynamics diagram of the allocated management time required for improvement, and the negative impact on management pressure and on managerial effectiveness.

The business unit manager of the machine shop recalled: "When we [the machine shop] are not achieving our targets [defect targets], it puts me under pressure... I get frustrated...".

He added: "...I have to get more and more involved in their [machine shop floor] activities... it does happen sometimes that my own work starts to lag behind, then I have to put extra effort in to catch up with my own work...". 


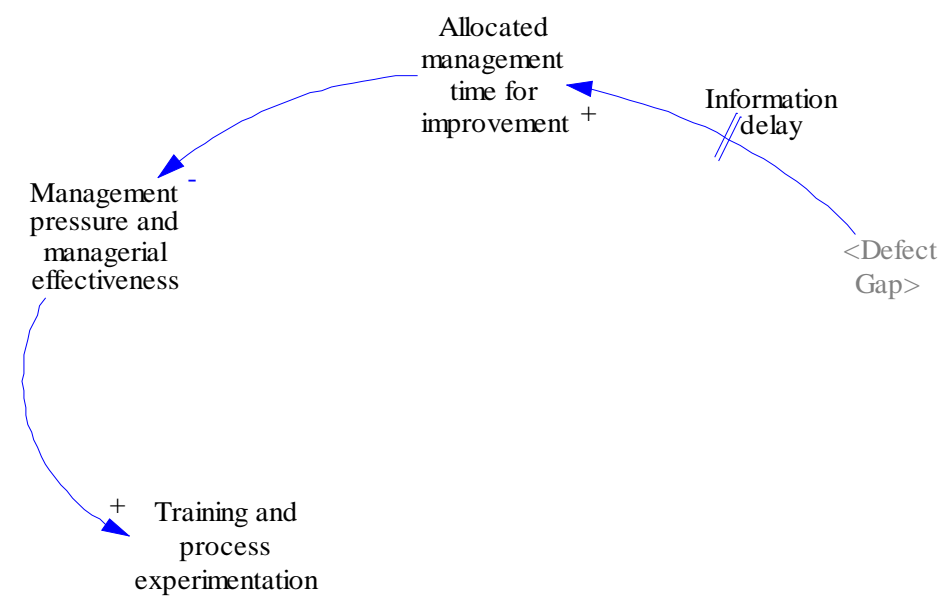

\section{Figure 12: System dynamics model of management pressure and managerial effectiveness}

The business unit manager of tear down recalled: "If I meet my target of cycle time [defect target], I go back to $30 \%$ focus on the improvement effort [quality improvement programme], but when I do not meet my target, I focus $70 \%$ of my time on the improvement effort". The increased focus on the quality improvement programme could lead to management actions such as training and process experimentation, in order to fix the process problems and ultimately reduce the number of defects. The operational excellence manager recalled: "... if there is something wrong on the machine, we stop the machine and do a machine capability study [process experimentation] in order to fix the machine".

Explaining how they go about finding the process problems, the quality inspector commented: "We involved Industrial Engineering... to modify the method [machining method of forgings] in accordance to the operator's understanding. We also studied the geometry of the machine..." .

The link to training and process experimentation closes the feedback loop between defects and problem correction in the system dynamics model (Figure 13). The benefit from training and process experimentation is not immediately realised, but only after some time has passed - hence the delay. The problem correction reduces the stock of process problems, which in turn reduces the rate of defect introduction, ultimately reducing the stock of defects. The feedback loop, or sustainability loop, is a balancing feedback loop (B5) with the inherent behaviour of exponential decay with goal-seeking (Figure 14).

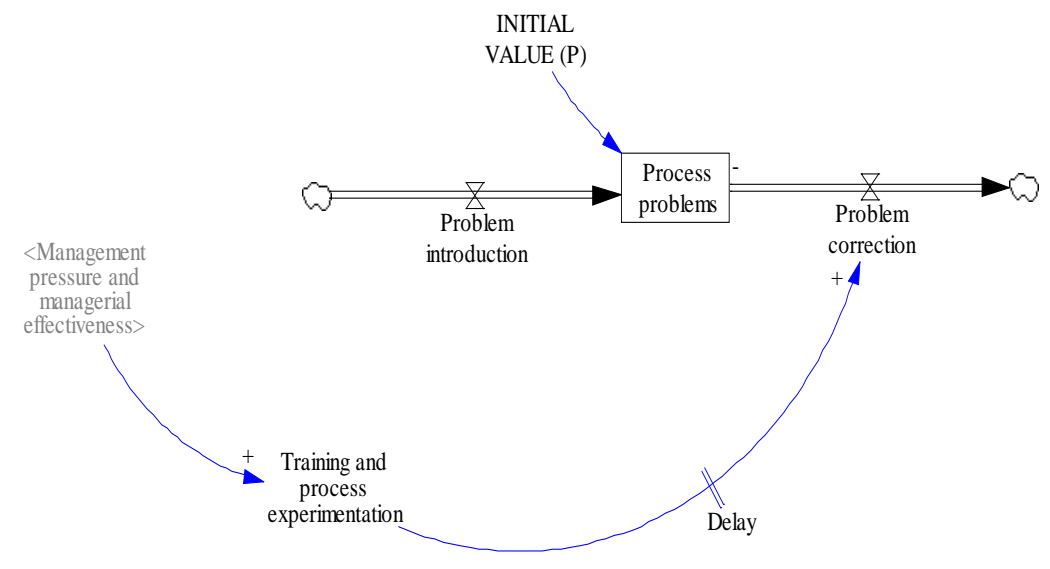

Figure 13: System dynamics model of training, process experimentation, and problem correction 


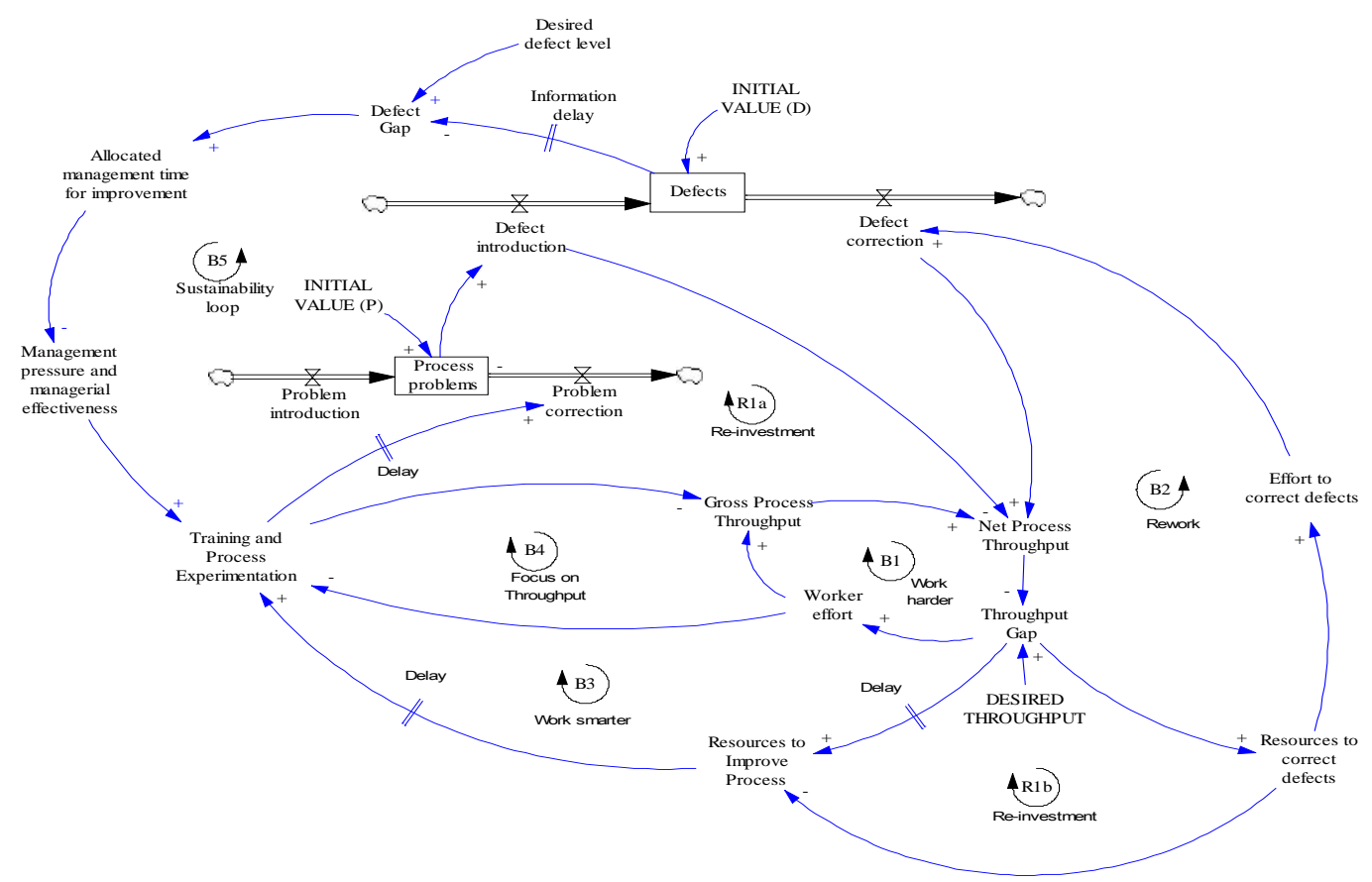

Figure 14: System dynamics model with a sustainability balancing feedback loop (B5), from a systems thinking perspective

\section{Conclusion}

A theory on sustainability has been developed from a systems thinking perspective, grounded in the literature and case study data. The system dynamics model depicted in Figure 14 describes the sustainability feedback loop (B5), fundamentally developed from the case study data and based on the baseline structure of the theory developed by Repenning and Sterman [10]. This is a contribution to the body of knowledge, and assists in eventually addressing in more detail the research questions posed in section 2.

The sustainability balancing loop (B5) creates the information feedback required for the measurement of the defects and for comparing it with the desired defect level, as fundamentally suggested by Figures 2 and 3. The information about the defect gap is used by the agents in the system to investigate the process problems through training and process experimentation. As a previous study from Olivia and Rockart has suggested, managerial time and the use of continuous improvement tools are important for sustainable improvement programmes [7].

From the archived data and interviews during the polar type case study design, in the case of the machine shop, the agents in the system followed the work smarter loop (B3), using continuous improvement tools, and the sustainability feedback loop (B5) depicted by the measurement processes. The measurement processes drove the exponential decaying behaviour of the defects, as depicted in Figure 5, from May 2010 to Dec 2010.

The theory for sustainability developed here can be developed in further research into a system dynamics simulation model that includes the dynamic impact of less tangible factors such as management pressure and managerial effectiveness. Further research currently being undertaken also includes the full mathematical derivation and computer simulation of the system dynamics model for sustainability that was developed in this paper. 


\section{REFERENCES}

[1] Oakland, J.S. 2003. Total Quality Management, text with cases. Butterworth, Heinemann.

[2] Bhuiyan, N. \& Baghel, A. 2005. An overview of continuous improvement: from the past to the present. Management Decision, 43, pp 761-771.

[3] Sterman, J. 2000. Business dynamics. Systems thinking and modeling for a complex world. McGraw Hill Higher Education.

[4] Baines, T.S. \& Harrison, D.K. 1999. An opportunity for system dynamics in manufacturing system modelling. Production Planning and Control 10(6), pp 542-552.

[5] Newton, P. 2003. System dynamics in Six Sigma practice. $21^{\text {st }}$ System Dynamics Conference, pp 128.

[6] J ones, A., Krahmer, E., Olivia, R., Repenning, N., Rockart, S. \& Sterman, J. 1996. Comparing improvement programs for product development and manufacturing: Results from field studies. $14^{\text {th }}$ International Conference of the System Dynamics Society 1996, pp 245-248.

[7] Oliva, R. \& Rockart, S. 1997. Dynamics of multiple improvement efforts: The program life cycle model. $15^{\text {th }}$ International Conference of the System Dynamics Society 1997, pp 1-6.

[8] Curry, A. \& Kadash, N. 2002. Focusing on key elements of TQM - evaluation for sustainability. The TQM magazine, 14(4), pp 207-216.

[9] Buchanan, D., Fitzgerald, L., Ketley, D., Gallop, R., J ones, J .L., Saint Lamont, S., Neath, A. \& Whitby, E. 2005. No going back: A review of the literature on sustaining organizational change. International J ournal of Management Reviews, 7(3), pp 189-205.

[10] Repenning, N.P., Sterman J. D., 2002. Capability traps and self confirming attribution errors in the dynamics of process improvement. Administrative Science Quarterly, 47, pp 265-295.

[11] Van Dyk, D. \& Pretorius, L. 2012. A system dynamics approach to quality improvement programs in a heavy engineering manufacturing environment. Proceedings of PICMET '12: Technology management for emerging technologies, pp 3287-3296.

[12] Besterfield, D.H., Besterfield-Minchna, C., Besterfield, G.H. \& Besterfield-Sacre, M. 2003. Total quality management. Pearson Education International

[13] Hancock, D.R. \& Algozzine, B. 2006. Doing case study research. A practical guide for beginning researchers. Teachers College Press, Columbia University.

[14] Gillham, B. 2000. Case study research methods. Real World Research, Continuum, London.

[15] Eisenhardt, K.M. 1989. Building theories from case study research. Academy of Management Review, 14, pp 532-550.

[16] Meredith, J. 1998. Building operations management theory through case and field research. J ournal of Operations Management, 16, pp 441-454.

[17] Mouton, J. 2001. How to succeed in your masters and doctoral studies: A South African guide and resource book. Van Schaik, Pretoria.

[18] Rule, P. \& J ohn, V. 2011. Your guide to case study research. Van Schaik, Pretoria.

[19] Luna-Reyes L.F., Anderson D.L., 2003. Collecting and analysing qualitative data for system dynamics: Methods and models. System Dynamics Review, 19(4), pp 271-296.

[20] Morecroft J., D.,W., Sterman, J.,D. 1994. Modeling for learning organizations. Productivity Press, Portland, OR.

[21] Brassard, M., Finn, L., Ginn, D. \& Ritter, D. 2002. The Six Sigma memory jogger II, A desktop guide of tools for Six Sigma improvement teams. GOAL/ QPC NH.

[22]Schneiderman, A.M. 1988. Setting quality goals. Quality Progress, pp 55-57.

[23] Mullins, L.J., 1996. Management and organisational behaviour. $4^{\text {th }}$ edition, Pitman Publishing.

[24] Bateman, N. \& Rich, N. 2003. Companies' perceptions of inhibitors and enablers for process improvement activities. International J ournal of Operations \& Production Management, 23(2), 185-199.

[25] Zairi, M. 2002. Beyond TQM implementation: The new paradigm of TQM sustainability. Total Quality Management, 13(8), 1161-1172.

[26] Meredith, J.R., Shafer, S. M., 2011. Operations management, $4^{\text {th }}$ edition, John Wiley \& Sons, Inc.

[27] Stamatis, D.H. 2003. Six Sigma and beyond. Design for Six Sigma. St. Lucie Press.

[28] Forrester, J.W. 1989. The beginning of system dynamics. International meeting of the System Dynamics Society, Stuttgart, J uly, 1989, 1-1. 